\title{
Investigating ACF Policy Change Theory in a Unitary Policy Subsystem: The Case of Ghanaian Public Sector Information Policy
}

B. Timothy Heinmiller, Emmanuel M. Osei and Eugene Danso

\section{(2) OpenEdition}

\section{Journals}

Electronic version

URL: https://journals.openedition.org/irpp/1894

DOI: 10.4000/irpp.1894

ISSN: 2706-6274

\section{Publisher}

International Public Policy Association

\section{Printed version}

Date of publication: 15 March 2021

ISSN: 2679-3873

\section{Electronic reference}

B. Timothy Heinmiller, Emmanuel M. Osei and Eugene Danso, "Investigating ACF Policy Change Theory in a Unitary Policy Subsystem: The Case of Ghanaian Public Sector Information Policy", International Review of Public Policy [Online], 3:1 | 2021, Online since 15 March 2021, connection on 17 June 2021. URL: http://journals.openedition.org/irpp/1894 ; DOI: https://doi.org/10.4000/irpp.1894

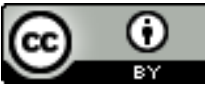

International Review of Public Policy is licensed under a Creative Commons Attribution 4.0 International. 


\section{Investigating ACF Policy Change Theory in a Unitary Policy Subsystem: The Case of Ghanaian Public Sector Information Policy}

\section{B. Timothy Heinmiller}

Brock University, Canada

\section{Emmanuel M. Osei}

Ph.D Student, University of Toronto, Canada

\section{Eugene Danso}

Concordia University, Canada

\section{Abstract}

In 2019, the government of Ghana overhauled its access to public information rules through the Right to Information Act. Prior to this legislation, access to public sector information was not formally regulated and the new legislation provided a legal framework for making public sector information accessible to the general public. From an Advocacy Coalition Framework (ACF) perspective, the passage of the Right to Information Act represents a major policy change and provides a case in which the ACF theory of major policy change can be investigated. This case is also interesting because it took place in a unitary policy subsystem, as opposed to a competitive or collaborative subsystem. Unitary subsystems are characterized by a single, dominant advocacy coalition, in this case a pro-transparency coalition, and are relatively uncommon in the ACF literature. The purpose of this paper is to investigate ACF policy change theory in the Ghanaian public sector information policy subsystem - as a unitary subsystem - to determine whether it can explain the major policy change that took place with the passage of the Right to Information Act. The investigation finds strong empirical support for the ACF's 'pathways' hypothesis and moderate support for the 'power' hypothesis.

\section{Keywords}

Advocacy Coalition Framework, Ghana, policy change theory, unitary policy subsystem 


\section{Introduction/Background}

In 2019, the government of Ghana overhauled its access to public information rules through the Right to Information Act. Prior to this legislation, access to public sector information was not formally regulated. Public institutions were under no obligation to honour information requests and generally exercised arbitrary discretion on the kinds of information suitable for public consumption (Kuunifaa, 2012). The adoption of the Right to Information Act provided a legal framework for making public sector information accessible to the general public. The law ensured that, with the exception of sensitive information exempt from public access, Ghanaians had the right to access information in the custody of public sector organizations. The law effectively guaranteed maximum disclosure of information and the government was enjoined to furnish the public proactively with information (Yawson, Armah, \& Dadzie, 2010, p. 330).

From an Advocacy Coalition Framework (ACF) perspective, the passage of the Right to Information Act represented a major policy change and provides a case in which the ACF theory of major policy change can be investigated. The ACF defines a major policy change as one involving the introduction of new core attributes to a policy, shifting policy in a new direction in pursuit of new objectives. Prior to the 2019 reforms, Ghana's access to information regime rested on the government's discretionary powers and was mostly designed to allow the government to avoid public scrutiny. After the reforms, the presumptive policy objective is government transparency, institutionalizing a process of access to information and reducing government's control over the release of information, even information that might be embarrassing to it. Thus, a shift in the policy's core attributes - from government opacity to government transparency - has taken place and the Right to Information Act constitutes a major policy change.

For ACF scholars, the Right to Information Act provides an intriguing case due to the nature of the policy subsystem that produced it. Anecdotal evidence suggests, and empirical investigation in this paper confirms, that the Ghanaian public sector information policy subsystem was unitary in structure, as opposed to competitive or collaborative. Unitary subsystems are characterized by a single, dominant advocacy coalition, in this case a pro-transparency coalition, and are relatively uncommon in the ACF literature.

Currently, it is assumed that ACF policy change theory applies to all policy subsystems regardless of their structure and this case allows us to probe this assumption by investigating the theory in an atypical subsystem type. Unitary subsystems have a distinctive politics and it is reasonable to question whether current theory adequately captures and accounts for this politics. Accordingly, the purpose of this paper is to investigate ACF policy change theory in the Ghanaian public sector information policy subsystem - as a unitary subsystem - to determine whether it can explain the major policy change that took place with the passage of the Right to Information Act in 2019. ${ }^{1}$ The investigation finds strong empirical support for the ACF's "pathways" hypothesis and moderate support for the "power" hypothesis.

This study is also the first application of ACF policy change theory to Ghanaian policymaking. Previous Ghanaian applications have used elements of the framework to inform their analyses, demonstrating its viability in the Ghanaian context, but have not formally investigated the ACF theory of policy change. Accordingly, this article opens an important line of research, providing insights into democratic policymaking in Ghana, as well as insights into the functionality of ACF theory in a non-Western democratic context.

1 - In Ghana, some actors use the terms 'public sector information policy' and 'Right to Information Act' interchangeably. In our use of these terms, public sector information policy is the policy area being studied and the Right to Information Act is a specific policy outcome - a major policy change - in this policy area. 


\section{Theoretical Framework: The Advocacy Coalition Framework (ACF)}

First developed by Paul Sabatier and Hank Jenkins-Smith in the late 1980s, the ACF has been one of the most widely applied policy process theories of the last two or three decades.

The unit of analysis in the ACF is the policy subsystem and within each policy subsystem are the various actors who claim a stake in a policy area and who regularly participate in policy processes. The boundaries of any policy subsystem are defined by both a substantive focus and a geographical scope (Sabatier \& Weible, 2007, p. 193) which, in this case, is access to public sector information within Ghana. The ACF further assumes that actors in a policy subsystem are fundamentally driven by their beliefs and their desire to see their beliefs reflected in policy. The framework distinguishes between beliefs operating at three different levels of abstraction. At the deepest level are deep core beliefs, which are quite broad in scope, predominantly normative, and very slow to change in response to empirical contradiction. These beliefs are relevant across a broad range of policy subsystems and include such things as one's left-right ideological orientation. At the next deepest level are policy core beliefs which are intermediate in scope because they involve the application of deep core beliefs to a specific policy subsystem. Policy core beliefs are resistant to change, "...but are more likely to adjust in response to verification and refutation from new experience and information than deep core beliefs" (Weible, Sabatier, \& McQueen, 2009, p. 123). At the shallowest level are secondary beliefs which are narrowest in scope and which pertain to the details of various policy issues, such as preferred modes of policy implementation. Although secondary beliefs are linked to policy core beliefs, they are more empirically based and are therefore more amenable to change (Sabatier \& Weible, 2007, pp. 194-96).

Actor beliefs are important in the ACF because policy core beliefs, the mid-level beliefs described above, serve as the rallying point for advocacy coalitions. Like-minded actors in policy subsystems often make common cause in pursuit of their policy goals simply because they are more effective working together than working in isolation. When a group of actors shares a set of policy core beliefs and engages in a non-trivial degree of collective action, they form an advocacy coalition (Sabatier \& Weible, 2007, p. 196). The ACF hypothesizes - and research has largely confirmed - that advocacy coalitions tend to be relatively stable over time, despite some turnovers in coalition membership, so that, on most major controversies in a policy subsystem, there is a characteristic line-up of coalitions seeking to influence policy (Jenkins-Smith, Nohrstedt, Weible, \& Sabatier, 2014, p. 195). The number of advocacy coalitions in a policy subsystem typically ranges between one and five, with the exact number constituting an empirical question (Sabatier, 1993). Advocacy coalitions are central in ACF theory because the dominant coalition in any policy subsystem shapes the policy decisions made. 
Figure 1: A Diagram of the Advocacy Coalition Framework

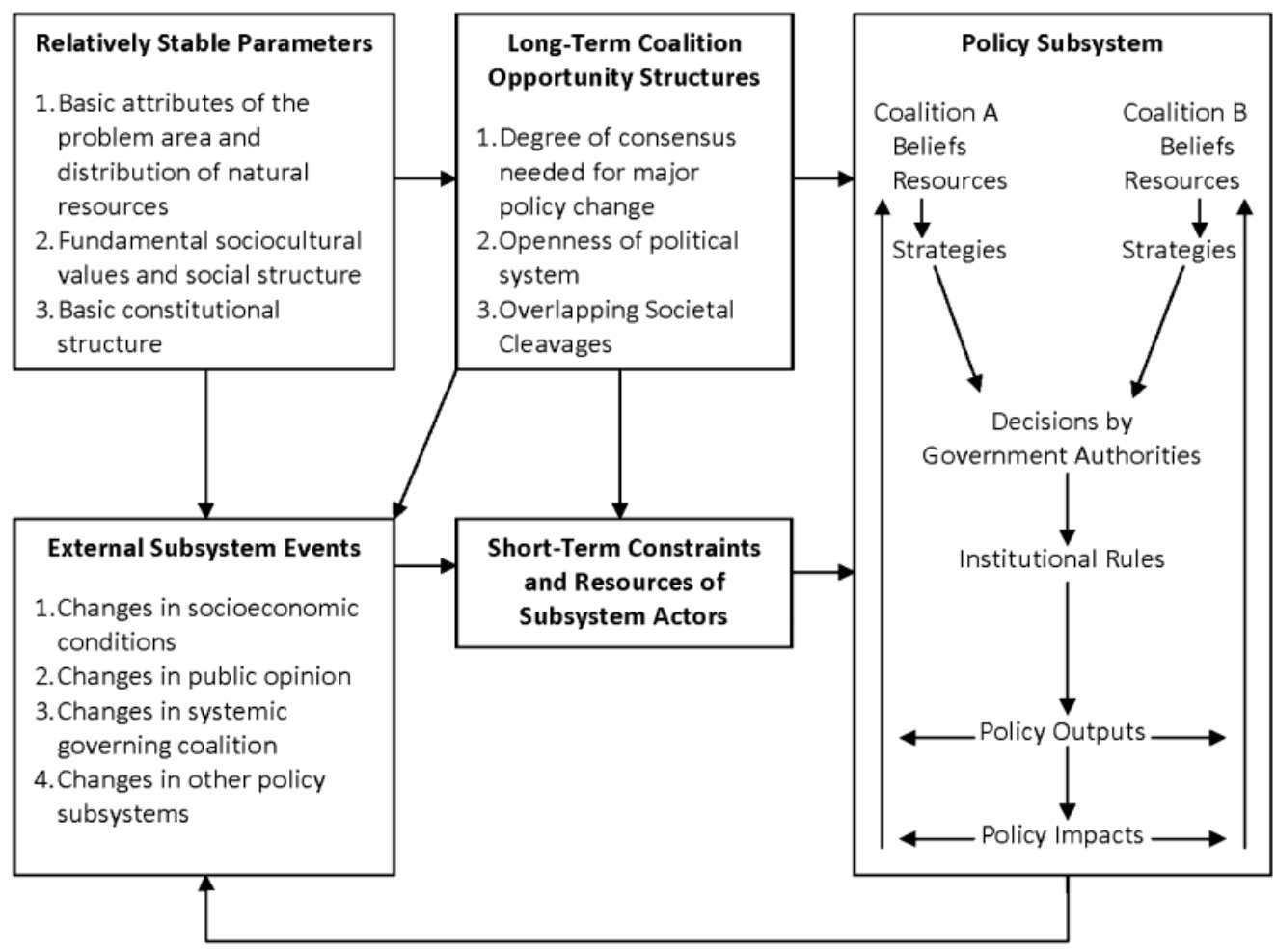

Source: Weible et al. (2011, p. 352)

Since its inception, the ACF has spawned three lines of theory relevant to policy and policymaking: a theory of advocacy coalitions; a theory of policy-oriented learning; and a theory of major policy change. Each line has developed distinctive hypotheses which have been repeatedly tested in empirical research. These empirical results have informed periodic revision of the hypotheses and even some revisions to the framework itself. While all three lines of theory are relevant, the most pertinent to this study is the theory of major policy change, which outlines the factors causing such change.

The ACF has a distinctive conception of public policy that differentiates between major and minor policy change. In the ACF, policies are assumed to be interpretations and reflections of policy-oriented beliefs. Just as policy-oriented beliefs have core and secondary aspects, so too do public policies. Core aspects of a policy have to do with its overall direction and goals, and a change in the core attributes of a policy is considered a major policy change. In contrast, the secondary aspects of a policy pertain to the implementation of core goals, and a change in the secondary attributes of a policy is considered a minor policy change (Jenkins-Smith, Nohrstedt, Weible, \& Sabatier, 2014, p. 201).

The ACF theory of policy change is a theory of major policy change. Minor policy changes are assumed to result from dominant advocacy coalitions accepting new secondary beliefs - sometimes reluctantly - and translating these beliefs into policy, but there is no explicit ACF theory of minor policy change. The ACF theory of major policy change consists of two distinct but 
inter-related hypotheses, each specifying a necessary condition, which together provide an explanation of major policy change.

The first hypothesis holds that at least one policy change pathway must be present for a major policy change to occur. It states:

Significant perturbations external to the subsystem, a significant perturbation internal to the subsystem, policy-oriented learning, negotiated agreement, or some combination thereof are necessary, but not sufficient, sources of change in the policy core attributes of a governmental program (Jenkins-Smith, Nohrstedt, Weible, \& Ingold, 2018, p. 147).

In other words, the hypothesis specifies four possible policy change pathways: a shock external to a policy subsystem, a shock internal to a policy subsystem, policy-oriented learning, and negotiated agreement between coalitions (Weible, Sabatier, \& McQueen, 2009, p. 124). These are each potential policy change pathways because they shake up a policy subsystem enough to create openings for major policy change. Multiple pathways may be at work in any given policy change, but the presence of at least one pathway is considered necessary for major policy change to occur.

The second ACF policy change hypothesis focuses more directly on advocacy coalitions and the balance of power between advocacy coalitions within a policy subsystem:

The policy core attributes of a government program in a specific jurisdiction will not be significantly revised as long as the subsystem advocacy coalition that instated the program remains in power within that jurisdiction - except when the change is imposed by a hierarchically superior jurisdiction (Jenkins-Smith, Nohrstedt, Weible, \& Ingold, 2018, p. 147).

This hypothesis claims that major policy change only occurs when the coalition that introduced the status quo policy is no longer in power, except when policy change is imposed by a hierarchically superior jurisdiction. Given the close relationship between coalitions' policy core beliefs and the core attributes of policy, this claim makes sense: when the coalition that installed the policy status quo is no longer in power, a new coalition with new core beliefs can shape policy and bring about major policy change.

While ACF policy change theory is limited to explaining major policy change, there are no limits to the scope of the theory in terms of policy subsystem structure; the theory is assumed to apply to all subsystems regardless of their structural characteristics. ACF scholars have identified two subsystem structural dimensions as particularly important: whether a subsystem is nascent or mature, and whether a subsystem is unitary, competitive, or collaborative.

The first dimension differentiates policy subsystems based on how long they have existed and how much they have developed. Nascent subsystems are those that are relatively recently formed, while mature subsystems are those that are more long-standing and further developed. Mature subsystems are far more common in the ACF literature and, as we will see, the Ghanaian public sector information policy subsystem is an example of a mature subsystem.

The second dimension differentiates policy subsystems based on the number of advocacy coalitions present and the level of conflict between them. Unitary subsystems have only a single dominant advocacy coalition and there is typically little conflict in these subsystems as most actors share similar policy core beliefs. Collaborative subsystems have two or more coalitions and the coalitions share some beliefs, usually at the secondary level, resulting in an intermedi- 
ate level of conflict and some coordination or cooperation across the coalitions. Competitive subsystems also have two or more coalitions but share few beliefs and typically compete with each other for policy influence, sometimes quite intensely (Weible, 2008). The differences between unitary, collaborative, and competitive subsystems represent different types of coalition politics in policymaking, and it is therefore reasonable to question whether a single policy change theory adequately explains major policy change in all three contexts. This is the question that we begin to address in this paper.

Although there has yet to be a comprehensive survey of the empirical frequency of each subsystem type, it is probably fair to say that unitary subsystems are relatively uncommon given the limited number of these that have been identified in the ACF literature. Only two ACF studies have explicitly identified unitary policy subsystems: Ingold and Gschwend (2014) and Rinscheid (2015). Both of these studies examine policymaking in unitary subsystems, and Nohrstedt and Weible (2010) speculate on how unitary subsystems will respond to external shocks, but no study has yet investigated the ACF policy change hypotheses in a unitary subsystem. This study will be the first to do so.

This study will also be the first to investigate ACF policy change theory in Ghanaian policymaking. The ACF was developed - and subsequently revised - with US and Western European democracies in mind and it is worthwhile applying the framework and its theories to younger, non-Western democracies in order to assess their applicability in these contexts (JenkinsSmith, Nohrstedt, Weible, \& Ingold, 2018, pp. 156-159). Thus far, the framework has been applied to Ghana in at least two studies, both with promising results. Ainuson (2009) used ACF hypotheses about coalition formation and policy-oriented learning in order to understand Ghanaian water policy processes and concluded that the framework provided an effective way of understanding these processes. Similarly, Marfo and McKeown (2013) used the ACF as a heuristic framework to explain a negotiated policy change in Ghanaian forestry policy and also concluded that the framework was useful in the Ghanaian context. Thus, there is literature showing the utility of the ACF for understanding some aspects of Ghanaian policy processes, but there are no formal applications of ACF policy change theory, and this study will provide a first test of the theory in the Ghanaian context.

\section{Methodology}

This paper uses a case study approach to probe the limits of ACF policy change theory. The case selected was the passage of the Ghanaian Right to Information Act in 2019 and this was chosen because it was a major policy change in a unitary subsystem. This allows us to investigate ACF policy change theory in a distinct subclass of major policy change cases. Such an approach follows the advice of George and Bennett (2005, p. 77), who argue that using a case study to investigate a subclass (major policy change in unitary subsystems) of a general phenomenon (major policy change in all subsystems) is a useful way of contributing to theory-building by testing a general theory within a specific and somewhat atypical context.

In this approach, the Right to Information Act is considered a "most likely" case in which ACF policy change theory is expected to work since there are no existing theoretical scope conditions that would preclude its application to this case (Gerring, 2007, pp. 120-121). If the theory is supported in our investigation, the theory's existing claim to general application across subsystem types is strengthened. If, however, the theory is not supported in our investigation, then we must consider whether unitary subsystems require differential treatment in ACF policy change theory. Either way, testing the ACF policy change hypotheses in the Right to Information Act case makes a contribution to the ongoing development of the theory. 
We investigate the development of the Right to Information Act using the congruence method. Our approach is congruence, rather than process tracing, since we operationalize and investigate causal factors - the ones outlined in ACF policy change theory - but do not posit and investigate explicit mechanisms linking the causal factors and the outcome of major policy change (Beach \& Pedersen, 2016, pp. 269-71). We do not investigate explicit causal mechanisms as none are specified in current ACF policy change theory, making them beyond the scope of the current analysis.

Much of the data for this paper are derived from a content analysis of Ghanaian media articles using methods similar to Olofsson, et al. (2018) and Heikkila et al. (2019).The sample of articles was created using ghanaweb.com, a website that serves as a clearinghouse for Ghanaian news stories. Ghanaweb.com provided the most comprehensive archive of Ghanaian news stories that we could find, providing coverage from 2001 to 2019, which we took as our period of study. The ghanaweb.com news archives were searched for the following terms: "right to information bill" and "freedom of information bill" in order to identify relevant articles. These searches produced 826 news stories which were reviewed to remove duplicate stories, columns and opinion pieces, and stories that made no reference to a policy actor. The sample was further limited to include only articles from the Ghana News Agency, the Daily Graphic Online, and myjoyfmonline, three news outlets judged as credible due to their non-affiliations with political parties or political movements and their relatively muted ideological orientations. A total of 256 articles was included in the final sample. Media articles as a data source have the benefits of being accessible, low-cost, and replicable, but reliance on them also limits the data to what is reported in the media and we tried to overcome this limitation by supplementing our analysis of media articles with data from other sources.

The purpose of the content analysis was to identify the actors who were active in the policy subsystem, to identify these actors' policy core beliefs, and to identify patterns of agreement and disagreement between them. The media articles did not provide coverage of all the actors in the policy subsystem, but did provide coverage of the most high-profile actors, which was sufficient for identifying advocacy coalitions. The coding unit in the content analysis was the descriptions of policy actors. The article sample was segmented by reviewing each article and identifying all instances in which an actor was described as being involved in freedom of information debates or processes in any way. Each actor description was given a unique identification number and was subsequently coded, the coding decisions guided by a coding frame.

The coding frame was designed to capture several relevant actor attributes, including: individual names, organizational affiliations (if any), organizational types (political parties, domestic NGOs, international NGOs, etc.), policy core beliefs (whether they were pro or anti freedom of information), policy core belief rationales (their justifications of their pro/anti stand), agreements with other actors, and disagreements with other actors. Appendix A lists these coding dimensions and the categories used in each dimension.

The coding frame was outlined in detail in a coding guide and, using this common coding guide, two coders coded the sample independently. The coding results with respect to policy core beliefs - the most important actor attribute from an ACF perspective - were then compared and all coding discrepancies were identified. These discrepant coding units were removed from the dataset so that there was 100 percent agreement between the coders, ensuring a high degree of inter-coder reliability on this crucial attribute. The final dataset had a total of 360 coding units with 84.7 percent agreement between the coders on organizational type and 83.1 percent agreement on core belief rationales. Any remaining coding discrepancies on these attributes 
were treated as unreliable and excluded from the analysis. The data on agreements and disagreements between actors proved to be unreliable, with only 69.7 percent agreement between the coders, and these were excluded from the analysis.

The content analysis data, supplemented with other observations, were used to investigate the presence of advocacy coalitions in the policy subsystem, thereby determining the subsystem's structure. The data on policy core beliefs were analyzed to determine which ideological groupings, at the policy core level, existed in the policy subsystem. Observations of collective action within each ideological grouping were then sought in the public record to determine whether there was a non-trivial level of collective action amongst actors holding the same policy core beliefs, which would indicate the presence of an advocacy coalition. Ultimately, the number of advocacy coalitions supported by the data indicated the policy subsystem structure which, in this case, was unitary.

We then investigated the first ACF policy change hypothesis by operationalizing the policy change pathways that may be present in this case: internal shocks, external shocks, and policyoriented learning. The negotiated agreement pathway - a fourth pathway specified in the hypothesis - was not operationalized or investigated given the structure of the subsystem. The negotiated agreement pathway is logically impossible in a unitary subsystem since the subsystem, by definition, has only a single dominant coalition and negotiated agreements between multiple coalitions are precluded. Any negotiation in such a subsystem will be intra-coalition and will likely be restricted to secondary policy attributes.

Internal/external shocks were operationalized using data on media coverage from ghanaweb. com. The assumption in this operationalization is that, when a policy subsystem experiences a shock, it should be evident through increased subsystem activity and increased media coverage of that subsystem. We collected data on the number of new stories matching the search terms "right to information" and "freedom of information" with the data aggregated by annual quarter for our entire period of study. We analyzed this data by looking for substantial spikes in media coverage, taking into consideration the fact that the extent of online news coverage increased over time during our period of study. Spikes in media coverage were then investigated to determine the reasons for each spike, whether these reasons constituted shocks to the subsystem, and whether each shock was internal or external to the subsystem.

Policy-oriented learning was operationalized using data from the content analysis. The content analysis coded for actors' policy core beliefs as well as their rationales for these core beliefs, and we examined these data to determine whether there was any shift in core beliefs or core belief rationales that might indicate the presence of policy-oriented learning. The data spanned 2001 to 2019 and were divided into four time periods, each period corresponding with a different presidential administration and different efforts to pass freedom of information legislation. The beliefs in each of these four time periods were analyzed to look for any evidence of shifting beliefs between these periods, which might indicate the presence of policy-oriented learning.

The second ACF policy change hypothesis was investigated by operationalizing its two hypothesized causal factors: policy imposition by a hierarchically superior jurisdiction, and the advocacy coalition(s) "in power". Since the only jurisdiction with the potential to impose policy on the Ghanaian parliament was the Supreme Court of Ghana, policy imposition was operationalized by investigating events surrounding the adoption of the 2019 Right to Information Act to determine whether it was motivated or compelled by a Supreme Court decision. To operationalize the second hypothesized factor, we drew on the ACF literature to determine when an ad- 
vocacy coalition is "in power". Sabatier and Weible (2007, pp. 201-204) have identified several political resources that advocacy coalitions can draw upon in seeking power, including public opinion, information, mobilizable troops, financial resources, skilful leadership, and formal legal authority to make policy decisions. Nohrstedt (2011) and Heinmiller (2013) (2016) have further argued that, out of these, the most important resource is the formal legal authority to make policy decisions because wielding influence over legislators is necessary to get policy reforms through the veto points of the legislative process. Thus, we considered an advocacy coalition to be "in power" if it was aligned with a political party possessing the formal legal authority in the Ghanaian political system to make policy decisions.

\section{Data Analysis and Results: Structure of the Ghanaian Public Sector Information Policy Subsystem}

The first step in our analysis was to investigate the structural characteristics of the Ghanaian public sector information policy subsystem. This analysis, based largely on the content analysis data, revealed that the subsystem was unitary and mature.

The policy core belief data from the content analysis overwhelmingly show that the Ghanaian public sector information policy subsystem was dominated by a pro-transparency advocacy coalition, supporting greater freedom of public information, throughout our period of study. Only one actor in the entire dataset had anti-transparency beliefs, with all others showing either pro-transparency beliefs or unclear beliefs. Appendix B shows the organizations, excluding individuals without organizational affiliations, which were politically active and which espoused pro-transparency beliefs during the four presidential administrations of our period of study. It shows how pro-transparency actors came from a wide variety of organizations and organizational types, with even the two major political parties, the left-leaning National Democratic Congress (NDC) and the right-leaning New Patriotic Party (NPP), both espousing pro-transparency beliefs. All of this shows the degree of core-belief consensus in the policy subsystem, characteristic of a unitary subsystem.

There is also evidence that several actors with pro-transparency beliefs undertook collective action in an effort to secure freedom of information reforms. The best and most important example of this was the formation of the Right to Information Coalition-Ghana (RTI-Ghana) in 2003, the members of which are bolded in Appendix B. RTI-Ghana was an umbrella group comprising several organizations representing lawyers, journalists, and democracy and civil rights advocates, and which also had participation and support from several transnational organizations including the Commonwealth Human Rights Initiative and the West Africa Media Foundation. RTI-Ghana formed the core of the pro-transparency advocacy coalition and played a crucial role in educating the public, rallying supporters, and lobbying government until the 2019 legislation was adopted (Commonwealth Human Rights Initiative Africa Office, 2019, p. 14). The presence of RTI-Ghana shows clear evidence of collective action amongst many actors with pro-transparency beliefs, confirming the presence of a pro-transparency advocacy coalition. Moreover, this pro-transparency coalition was unopposed by an anti-transparency coalition, resulting in a unitary subsystem dominated by the former.

Evidence also suggests that the Ghanaian public sector information policy subsystem was a mature subsystem rather than a nascent one. To distinguish between nascent and mature subsystems, Sabatier and Jenkins-Smith (1999, pp. 135-36) outlined four necessary and sufficient characteristics of mature subsystems (shown in italics below), all of which appear to be present in our case: 
1. Subsystem participants who constitute a semiautonomous community and who share a domain of expertise. As shown in Appendix B, the subsystem had many actors with expertise in this policy domain, and who participated in freedom of information politics spanning multiple presidential administrations. These actors also had regular interaction and seem to constitute a semiautonomous community (Commonwealth Human Rights Initiative Africa Office, 2019).

2. Subsystem participants who have endeavoured to influence policy for a long period of time, usually a decade or more. The origins of the subsystem stretch back to at least the mid1990s when new motivations for transparent and accountable governance emerged after Ghana's 1992 transition to democracy in the Fourth Republic. A freedom of information controversy erupted in 1996 when the Bank of Ghana refused to give information on interest rates, inflation rates and national debt to the Institute of Economic Affairs, a domestic thinktank, citing national security reasons. This incident motivated several actors to take up the freedom of information cause and prompted the first draft bill on the issue in 1999 (Yeboah, 2019)

3. The presence of specialized agencies to deal with the subsystem topic at all relevant levels of government. The Government of Ghana has had a Ministry of Information, sometimes on its own and sometimes merged with another ministry, throughout the Fourth Republic and even before. The Ministry of Information also shows up as a regular participant in freedom of information policy debates in multiple presidential administrations, as shown in Appendix B.

4. The presence of interest groups that have mobilized to deal with the subsystem topic. Organized interests dedicated to government transparency in Ghana have existed for some time, the best examples being those who formed the RTI-Ghana coalition in 2003.

While the Ghanaian public sector information policy subsystem is both unitary and mature, it is the unitary characteristic that offers a potential challenge to ACF policy change theory. Mature subsystems are quite common in the ACF literature and there is little reason to question whether ACF policy change theory has application in these subsystems. However, unitary subsystems are uncommon in the ACF literature and have a distinctive politics that may challenge ACF policy change theory. For this reason, it is worth investigating the ACF policy change hypotheses in this unitary case to see how they fare, as we endeavour to do in the next two sections.

\section{Data Analysis and Results: Investigating the 'Pathways' Hypothesis}

As described above, the first ACF policy change hypothesis, the pathways hypothesis, was investigated by collecting data on internal/external shocks and on policy-oriented learning.

The data on internal/external shocks show several potential shocks during our period of study. Figure 2 shows the number of new stories on "right to information" and "freedom of information" in each annual quarter of our period of study, as compared with a five-year rolling average. The data have been adjusted to show only positive variance; that is, quarterly coverage that is above the mean. Any negative variance below the mean has been standardized to zero. Comparing quarterly coverage with a five-year rolling average was necessary in order to contextualize the data, as Internet news coverage increased steadily and substantially during our period of study for technological and social reasons that had nothing to do with the subsystem under study. The most relevant findings in Figure 2 are the substantial and short-lived spikes in media coverage that are evident at least five times during our period of study, as these are preliminary indications of internal or external shocks to the policy subsystem. 
The most pertinent of these spikes, for our purposes, occurred in the first and fourth quarters of 2018, just prior to the passage of the Right to Information Act in early 2019. We investigated events during and prior to this time to determine whether any might have qualified as being shocking to the policy subsystem. Given that most internal shocks are the results of policy failures, and that there was no status quo right to information policy at this time that could have failed, we discounted the possibility of an internal shock. Most external shocks in the ACF come from "External Subsystem Events" (see the ACF flow diagram in Figure 1) and four types of these events are identified: changes in socioeconomic conditions, changes in public opinion, changes in systemic governing coalition, and changes in other policy subsystems. Comparing actual events with these four event types, the evidence suggests at least three external shocks to the public sector information policy subsystem in the 2016-18 period.

The first external shock was a change in the systemic governing coalition when the NPP won the 2016 elections. The opposition NPP, under the leadership of Nana Akufo-Addo, secured $53.72 \%$ at the first round, defeating the incumbent President John Dramani Mahama, of the NDC, who managed $44.53 \%$ of the total valid votes. In Parliament, the NPP won overwhelmingly with 169 out of 275 seats, leaving the NDC with 106 seats (Electoral Commission of Ghana, 2016). This electoral verdict effectively guaranteed the incoming government exclusive executive and legislative control, creating an enabling environment for the pursuit of new policy priorities. During its eight-year rule, the NDC missed several opportunities to pass right to information reforms, including a last-ditch attempt that failed when Parliament expired in early 2017. In its election manifesto, the NPP promised to pass such reforms when it came to power (New Patriotic Party, 2016, p. 40), and the RTI coalition had cultivated good working relationships with some members of the NPP, so the change in government seemed to open a new window for reform and to add urgency to the RTI coalition's reform efforts.

The second external shock was a change in public opinion that developed from accumulated corruption scandals. Corruption has always been a major election issue in Ghana and the 2016 elections were no exception. During the campaign, the opposition NPP waged a strong anticorruption campaign, highlighting the corruption scandals that stunned the nation during the Mills/Mahama eight-year rule (2009-2016). Key among the scandals - which are summarized in Appendix C - were the Ghana Youth Employment and Entrepreneurial Development Agency (GYEEDA) scandal, the Bus Branding scandal, and the embezzlement of funds at the Savanna Accelerated Development Authority (SADA). The rest were the GHథ51.2 million WOYOMEGATE, the Mahama Ford Gift scandal and the financial malfeasance at the National Service Secretariat (Stacey, 2016; GhanaWeb, 2016; Gyampo, Graham, \& Yobo, 2017, p. 35). Many people, including the Executive Secretary of the Media Foundation for West Africa (MFWA), believed that the NDC government lacked the political will to be transparent and to fight corruption, hence its inability to pass right to information reforms (GhanaWeb, 2018a). Upon assuming office after the 2016 elections, the new NPP government commissioned independent audits across various state institutions, leading to additional allegations of financial malpractice involving officials of the past administration. Key among the new revelations were the Mobile Money Interoperability debacle (MyNewsGh, 2018), the Cocoa Marketing Board (COCOBOD) scandal (GhanaWeb, 2018b), and the Social Insurance and National Insurance Trust (SNNIT) software scandal (GhanaWeb, 2018c). The situation was further aggravated when scandals involving officials of the new government began to emerge in 2017. The Bulk Oil and Storage Transportation (BOST) saga (Ullo, 2018) and the Metro Mass Transit scandal (Kumsah, 2018) were significant among several allegations levelled against officials of the new regime. When prosecutions were not forthcoming, calls to fight corruption went wild and even key mem- 
bers of the ruling government threatened to campaign against Akufo-Addo. With the nearconsensus that significant measures were needed to fight corruption, the NPP government felt overwhelming pressure to act and the RTI bill became regarded as a crucial tool to improve transparency and reduce corruption.

The third external shock was an impact from another policy subsystem when the Special Prosecutor's Bill was passed in 2017, and Martin Amidu was appointed to the Special Prosecutor's position (Osei-Amoako, 2018; Osei, 2017). In addition to right to information reforms, the NPP promised to establish the Office of the Special Prosecutor, an institution independent of the executive, dedicated to investigating and prosecuting corruption cases involving political officeholders and politicians (New Patriotic Party, 2016). In December 2017, the Office of the Special Prosecutor was created by an Act of Parliament and Martin Amidu, a former Attorney General who served in the NDC regime from January 2011 to January 2012, was appointed as Ghana's first Special Prosecutor. Consequently, the first quarter of 2018 was dominated by discussions on corruption and on how to ensure that the new Special Prosecutor would be effective and there were loud calls from activists, opposition parties and civil society organizations to pass right to information reforms to support his work.

Altogether, the evidence in support of the presence of external shocks is compelling. A change in government, a change in public opinion, and a spillover from a related subsystem converged in early 2018 to focus unprecedented attention on the right to information issue and to motivate government action on the issue. During the 61st independence anniversary celebration in March, President Akufo-Addo suggested that the missing link in the corruption fight was a Right to Information Bill. After the summer holiday, this set off a flurry of subsystem activity in the third quarter of the year, as evidenced by the second spike in media attention during 2018, ultimately culminating in the passage of the Right to Information Act. Thus, there is not only strong evidence of external shocks, there is also strong evidence that these external shocks were contributors to the major policy change. 
Figure 2: Media Coverage of Freedom of Information Issues, 2001-19

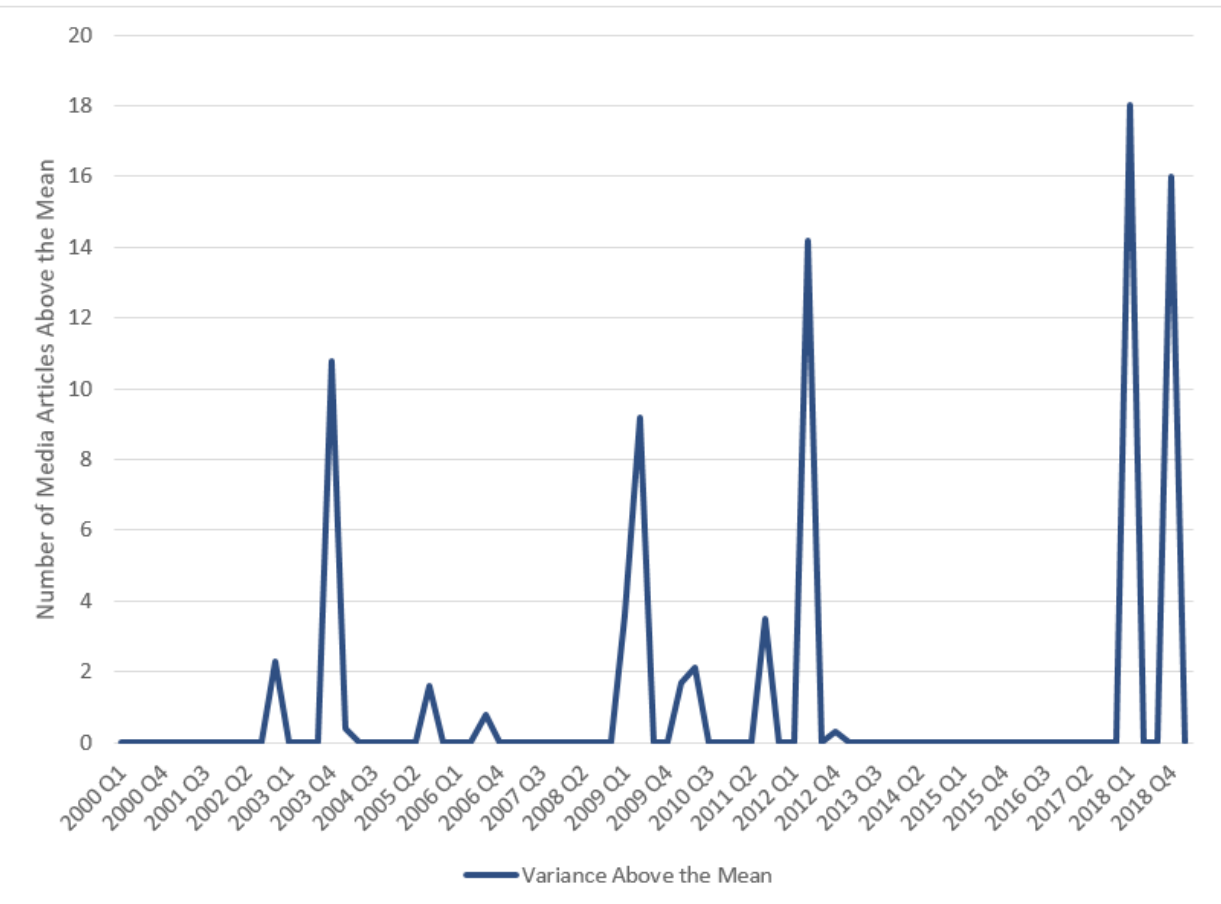

Source: The Authors

With respect to policy-oriented learning, neither the core belief data nor the core belief rationale data showed any evidence of policy-oriented learning. Given that pro-transparency core beliefs dominated throughout the entire period of analysis, there was no evidence of shifting policy core beliefs, as no actors flipped from anti-transparency to pro-transparency beliefs, or vice versa. The data on core belief rationales are summarized in Table 1 by providing the percentage of actors citing each rationale in each of the four time periods investigated. In all four periods, the overwhelmingly predominant rationale was one of fighting government corruption and improving government transparency, with all other rationales constituting minor parts of the discourse. This indicates that actors' justifications for supporting freedom of information legislation did not evolve much over time, that there was no mass movement from one rationale to another, and that policy-oriented learning at this level was not evident. Given that there was no evidence of significant changes over time in either policy core beliefs or core-belief rationales, we conclude that the policy-oriented learning pathway was probably not present in this case. 
Table : Pro-Transparency Belief Rationales, 2001-19

\begin{tabular}{|l|l|l|l|l|}
\hline $\begin{array}{l}\text { Rationales Cited for Support- } \\
\text { ing Freedom of Information } \\
\text { Legislation }\end{array}$ & $\begin{array}{l}\text { 2001-2009 } \\
\text { (Kufuor) }\end{array}$ & $\begin{array}{l}\text { 2009-2012 } \\
\text { (Mills) }\end{array}$ & $\begin{array}{l}\text { 2012-2017 } \\
\text { (Mahama) }\end{array}$ & $\begin{array}{l}\text { 2017-2019 } \\
\text { (Akufo- } \\
\text { Addo) }\end{array}$ \\
\hline $\begin{array}{l}\text { Fighting government corruption/ } \\
\text { improving government } \\
\text { transparency }\end{array}$ & $14(58.3 \%)$ & $25(58.1 \%)$ & $38(73.1 \%)$ & $14(43.8 \%)$ \\
\hline $\begin{array}{l}\text { Supporting economic growth/ } \\
\text { development }\end{array}$ & $0(0 \%)$ & $4(9.3 \%)$ & $2(3.8 \%)$ & $1(3.1 \%)$ \\
\hline $\begin{array}{l}\text { Legislation does not go far } \\
\text { enough (i.e., the legislation } \\
\text { allows too little access to } \\
\text { information) }\end{array}$ & $1(4.2 \%)$ & $2(4.7 \%)$ & $1(1.9 \%)$ & 0 (0\%) \\
\hline Improving journalism & $2(8.3 \%)$ & $3(7.0 \%)$ & $4(7.7 \%)$ & $3(9.4 \%)$ \\
\hline & 24 & 43 & 52 & 32 \\
\hline Total Actors & & & \\
\hline
\end{tabular}

Source: The Authors

Altogether, our investigation found considerable evidence supporting the presence of the external shock pathway, but found no evidence supporting the presence of the internal shock pathway, or the policy-oriented learning pathway. The negotiated agreement pathway was not investigated since the presence of only a single advocacy coalition made negotiated agreement between multiple coalitions impossible. While only one pathway was present, the presence of the external shock pathway alone is sufficient to support the first ACF policy-change hypothesis in this case.

\section{Data Analysis and Results: Investigating the 'Power' Hypothesis}

The second ACF policy change hypothesis is a necessary condition with two sufficient parts: one of these is policy imposition by a hierarchically superior jurisdiction, and the other is that the advocacy coalition that instated the policy status quo is no longer "in power". Each of these sufficient factors was operationalized independently to investigate this hypothesis.

The results with respect to policy imposition are straightforward. Only the Supreme Court of Ghana had the authority to impose the 2019 Right to Information Act on the Ghanaian Parliament, but an investigation of events leading to the introduction of the Act found no connection between a court decision and the reform. Thus, there is no evidence of policy imposition in this case and this part of the hypothesis is not supported.

The second part of the hypothesis was operationalized based on whether an advocacy coalition was aligned with a political party possessing the formal legal authority to make policy decisions, and the results are more complex. 
In Ghana's Fourth Republic, the formal legal authority to make policy decisions is shared between the parliament and the presidency, both of which are veto points in the legislative process. Thus far, every election has resulted in the same political party controlling both the parliament and the presidency simultaneously, with periods of power alternating between the NDC and the NPP. The content analysis data show that, for our entire period of study, both the NDC and the NPP held pro-transparency core beliefs, aligning with, and sometimes participating in, the pro-transparency advocacy coalition that dominated the Ghanaian public information policy subsystem. This indicates that the pro-transparency coalition was in power, and that an anti-transparency coalition could not have been in power, in the lead-up to the 2019 reforms, which is consistent with the second ACF policy change hypothesis.

However, the hypothesis also implies that, sometime prior to our period of analysis, there was an anti-transparency coalition that was displaced from power by the pro-transparency coalition revealed by our analysis. This anti-transparency coalition would have been responsible for instating the policy status quo that was replaced by the 2019 Right to Information Act. Given the non-democratic governments in Ghana's recent past, such an anti-transparency coalition is plausible and even probable, but our data do not provide a direct observation of such a coalition and its past presence and eventual displacement can only be inferred.

Overall, our investigation found no empirical support for the presence of policy imposition but some empirical support that the coalition that instated the policy status quo was no longer in power. It is clear that a pro-transparency coalition was in power during the passage of the 2019 reforms, but it is less clear whether there was an anti-transparency coalition in the past that was displaced from power by the pro-transparency coalition, as the hypothesis implies. Thus, the available evidence is consistent with the ACF second policy change hypothesis, but additional research beyond our period of study would provide more certainty that the hypothesis is fully supported.

\section{Discussion/Conclusion}

The main purpose of this paper was to investigate the ACF policy change theory in a unitary policy subsystem dominated by a single advocacy coalition. There is reason to believe that unitary subsystems have a different politics than their competitive and collaborative counterparts and that, therefore, the ACF policy change hypotheses might struggle to explain major policy change in unitary contexts. The unitary subsystem we examined was the Ghanaian public sector information subsystem and, specifically, the 2019 Right to Information Act reforms.

Our investigation found empirical support for both of the ACF policy change hypotheses, although the evidence supporting the first hypothesis was stronger than that supporting the second hypothesis. With respect to the first hypothesis, there is clear evidence that a series of external shocks buffeted the policy subsystem in the 2016-18 period, providing a pathway for major policy change. Although none of the other pathways were present, evidence of the external shocks is strong and the presence of this pathway alone is sufficient to support the first hypothesis. There is also empirical evidence supporting the second hypothesis, but it is more equivocal. Evidence suggests that a pro-transparency coalition was "in power" during the development of the Right to Information Act, which is consistent with the hypothesis's prediction, but we have no direct evidence that the pro-transparency coalition overcame an antitransparency coalition, as is implied in the hypothesis. So the available evidence is consistent with the hypothesis but is somewhat incomplete. 
Ultimately, we conclude that ACF policy change theory was largely successful in explaining this case of major policy change in a unitary policy subsystem. This provides some support for the theory's implicit claim to be a general explanation for major policy change across policy subsystems of all types. However, this study was the first to investigate the ACF policy change hypotheses in a unitary subsystem, so its findings do not confirm the hypotheses and further investigations in other unitary subsystems - and collaborative and competitive subsystems, for that matter - are warranted. Only through repeated and accumulated investigations of this sort will we be able to confirm ACF theory as a general theory of major policy change across all policy subsystem types.

This study was also the first to investigate ACF policy change theory in Ghanaian policymaking, with the results largely supporting the theory. This suggests that the ACF has at least some application in explaining how major policy changes take place in Ghanaian policymaking, even though the theory was developed with established Western democracies in mind and Ghana is a relatively young, non-Western democracy. Much further investigation, in other Ghanaian cases of major policy change, is needed before confirming the utility of ACF theory in this context, and this represents an important line of future research. Such research is also important for understanding how Ghanaian policymaking takes place and how Ghanaian democracy functions in practice.

\section{Bibliography}

Ainuson, K. (2009, December). An Advocacy Coalition Approach to Water Policy Change in Ghana: A Look at Belief Systems and Policy Oriented Learning. Journal of African Studies and Development, 1(2), 16-27.

Beach, D., \& Pedersen, R. B. (2016). Causal Case Study Methods: Foundations and Guidelines for Comparing, Matching, and Tracing. Ann Arbor, MI: University of Michigan Press.

Commonwealth Human Rights Initiative Africa Office. (2019, August). The Right to Information: Ghana's Journey (1992-2019). Retrieved from:

https://www.humanrightsinitiative.org/download/1570075247RTI\%20GHANAs\%20JOURNEY\%20(1992\%20-\%202019).pdf

Electoral Commission of Ghana. (2016). 2016 PRESIDENTIAL ELECTION RESULTS. Retrieved from: https://ec.gov.gh/wp-content/uploads/2019/10/2016-PRESIDENTIAL-ELECTION-RESULTS. docx.pdf

George, A. L., \& Bennett, A. (2005). Case Studies and Theory Development in the Social Sciences. Cambridge, MA: MIT Press.

Gerring, J. (2007). Case Study Research: Principles and Practices. Cambridge, MA: Cambridge University Press.

GhanaWeb. (2016, September 20). Eight scandals that have rocked the Mahama administration. GhanaWeb. Retrieved from:

https://www.ghanaweb.com/GhanaHomePage/NewsArchive/Eight-scandals-that-have-rockedthe-Mahama-administration-490932 
GhanaWeb. (2018a, January 4). NDC was not interested in graft fight - Braimah. GhanaWeb. Retrieved from:

https://www.ghanaweb.com/GhanaHomePage/NewsArchive/NDC-was-not-interested-in-graftfight-Braimah-614480

GhanaWeb. (2018b, July 17). Cocobod Scandal: Opuni trial begins. GhanaWeb. Retrieved from: https://www.ghanaweb.com/GhanaHomePage/NewsArchive/Cocobod-Scandal-Opuni-trial-begins -669442

GhanaWeb. (2018c, April 19). SSNIT Boss charged over \$72m scandal. GhanaWeb. Retrieved from: https://www.ghanaweb.com/GhanaHomePage/NewsArchive/SSNIT-Boss-charged-over-72m-scandal-644475

Gyampo, R. E., Graham, E., \& Yobo, E. (2017, June). Ghana's 2016 general election : accounting of the monumental defeat of the National Democratic Congress (NDC). Journal of African Elections, 16(1), 24-45.

Heikkila, T., Berardo, R., Weible, C. M., \& Yi, H. (2019). A Comparative View of Advocacy Coalitions: Exploring Shale Development Politics in the United States, Argentina, and China. Journal of Comparative Policy Analysis, 21(2), 151-66.

Heinmiller, B. T. (2013). Advocacy Coalitions and the Alberta Water Act. Canadian Journal of Political Science, 46(3), 525-547.

Heinmiller, B. T. (2016). Water Policy Reform in Southern Alberta: An Advocacy Coalition Approach. Toronto: University of Toronto Press.

Ingold, K., \& Gschwend, M. (2014). Science in Policy-Making: Neutral Experts or Strategic PolicyMakers? West European Politics, 37(5), 993-1018.

Jenkins-Smith, H. C., Nohrstedt, D., Weible, C. M., \& Ingold, K. (2018). The Advocacy Coalition Framework: An Overview of the Research Program. In C. M. Weible, \& P. A. Sabatier (Eds.), Theories of the Policy Process (4th ed., pp. 135-72). Boulder, CO: Westview Press.

Jenkins-Smith, H. C., Nohrstedt, D., Weible, C. M., \& Sabatier, P. A. (2014). The Advocacy Coalition Framework: Foundations, Evolution, and Ongoing Research. In C. M. Weible (Ed.), Theories of the Policy Process (3rd ed., pp. 183-223). Boulder, CO: Westview Press.

Kumsah, C. E. (2018, April 18). Metro Mass Transit Limited Scandal: MD asked to proceed on leave. Prime News Ghana. Retrieved from:

https://www.primenewsghana.com/general-news/metro-mass-transit-limited-scandal-md-askedto-proceed-on-leave.html

Kuunifaa, C. D. (2012, May 29). Access to information legislation as a means to achieve transparency in Ghanaian governance: Lessons from the Jamaican experience. IFLA Journal, 175-186.

Marfo, E., \& Mckeown, J. P. (2013). Negotiating the Supply of Legal Timber to the Domestic Market in Ghana: Explaining Policy Change Intent Using the Advocacy Coalition Framework. Forest Policy and Economics, 32, 23-31.

MyNewsGh. (2018, May 14). "RFP on controversial GH $₫ 4.6$ billion Mobile Money Interoperability". Retrieved from:

https://www.mynewsgh.com/read-full-contract-rfp-on-controversial-gh\%C2\%A24-6-billion-mobile-money-interoperability/

New Patriotic Party. (2016). Change: An Agenda For Jobs, Creating Prosperity and Equal Opportunity For All. Accra: CODEO, Ghana. Retrieved from:

http://codeoghana.org/assets/downloadables/npp_2016_manifesto.compressed.pdf 
Nohrstedt, D. (2011). Shifting Resources and Venues Producing Policy Change in Contested Subsystems: A Case Study of Swedish Signals Intelligence Policy. Policy Studies Journal, 39(3), 461-484.

Nohrstedt, D., \& Weible, C. M. (2010). The Logic of Policy Change After Crisis: Proximity and Subsystem Interaction. Risk, Hazards \& Crisis in Public Policy, 1(2), 1-32.

Olofsson, K. L., Katz, J., Costie, D. P., Heikkila, T., \& Weible, C. M. (2018). A Dominant Coalition and Policy Change: An Analysis of Shale Oil and Gas Politics in India. Journal of Environmental Policy \& Planning, 20(5), 645-60.

Osei, N. Y. (2017, November 16). Can Special Prosecutor Bill be mere semblance of commitment to fight corruption?. GhanaWeb. Retrieved from:

https://www.ghanaweb.com/GhanaHomePage/features/Can-Special-Prosecutor-Bill-be-mere-semblance-of-commitment-to-fight-corruption-600995

Osei-Amoako, Y. (2018, January 16). Reflections on Ghana's Office of the special prosecutor (1). GhanaWeb. Retrieved from:

https://www.ghanaweb.com/GhanaHomePage/features/Reflections-on-Ghana-s-Office-of-thespecial-prosecutor-1-618041\#: :text=The\%20process\%20of\%20approval\%20of\%20the\%20wouldbe\%20first,its\%20passage\%20by\%20Parliament\%20on\%20November\%2014\%2C\%202017.

Rinscheid, A. (2015). Crisis, Policy Discourse, and Major Policy Change: Exploring the Role of Subsystem Polarization in Nuclear Energy Policymaking. European Policy Analysis, 1(2), 34-70.

Sabatier, P. A. (1993). Policy Change Over a Decade or More. In P. A. Sabatier, \& J.-S. H. C., Policy Change and Learning - An Advocacy Coalition Approach (pp. 13-39). Boulder, CO: Westview Press.

Sabatier, P. A., \& Jenkins-Smith, H. C. (1999). The Advocacy Coalition Framework: An Assessment. In P. A. Sabatier (Ed.), Theories of the Policy Process (1st ed., pp. 117-66). Boulder, CO: Westview Press.

Sabatier, P. A., \& Weible, C. M. (2007). The Advocacy Coalition Framework - Innovations and Clarifications. In P. A. Sabatier, Theories of the Policy Process (pp. 189-220). Boulder, CO: Westview Press.

Stacey. (2016, December 14). Seven scandals that rocked the NDC under John Mahama. Pulse. Retrieved from:

https://www.pulse.com.gh/ece-frontpage/election-2016-seven-scandals-that-rocked-the-ndc-under-john-mahama/czxgc5y

Ullo, S. D. (2018, January 18). Major scandals that rocked Nana Addo's gov't worrying. Citifmonline. Retrieved from:

http://citifmonline.com/2018/01/major-scandals-rocked-nana-addos-govt-worrying-article/

Weible, C. M. (2008). Expert-based Information and Policy Subsystems: A Review and Synthesis. Policy Studies Journal, 36(4), 615-35.

Weible, C. M., Sabatier, P. A., \& McQueen, K. (2009). Themes and Variations: Taking Stock of the Advocacy Coalition Framework. Policy Studies Journal, 121-140.

Weible, C. M., Sabatier, P. A., Jenkins-Smith, H. C., Nohrstedt, D., Henry, A. D., \& deLeon, P. (2011). A Quarter Century of the Advocacy Coalition Framework: An Introduction to the Special Issue. Policy Studies Journal, 39(3), 349-360.

Yawson, D. O., Armah, F. A., \& Dadzie, S. K. (2010). Ghana's Right To Information Bill: Opportunity For SDI As A Technical Infrastructure. International Journal of Spatial Data Infrastructures Research, 5, 326-346. 
Yeboah, K. (2019, April 4). Passage of RTI Bill, the historical journey. Graphic Online. Retrieved from: https://www.graphic.com.gh/features/features/ghana-news-passage-of-rti-bill-the-historical-journey.html

\section{Appendix}

\section{Appendix A - Coding Frame for Content Analysis}

- Coding Unit Identification Number

- Each coding unit has a unique identification number in the format: DD-MM-YY-NN-AA

- Date

- The date the article was published in the format: YYYY-MM-DD

- Source

- The newspaper, website, broadcaster, or source of the article

- Actor's Name

- Their individual name, if provided in an article

- Actor's Organizational Affiliation

- The organization an actor represents, if provided in an article

- Actor's Organizational Type

- Coded as one of the following (select only one):

- Government

- A politician or staffer from the political party forming government at the national level

- Opposition

- A politician or staffer from a political party not forming government at the national level

- Public Servant

- An administrator working for a core government department or an arm's-length agency at the national level

- Local government

- A politician, staffer or administrator from a sub-national government

- Domestic NGO

- A non-profit advocacy or interest group that is based in Ghana and seeking social change in Ghana

- International NGO

- A non-profit advocacy or interest group that is based in Ghana and other countries and seeking social change in Ghana and other countries

- Industry/Business

- Private for-profit business or business representative

- International IGOs

- International organizations created by governments (e.g., World Bank, IMF, UN, etc.) 
- Journalist

- Print, broadcast, or online journalist or journalist representative

- Academic or consultant

- Researchers based in universities or private consulting firms

- Other

- Unclear

- Actor's Core Beliefs on Access to Government Information

- Coded as one of the following (select only one):

- Pro

- The actor states in the article that they are in favour of a general right to government information; or, the article describes the actor as being in favour of a general right to government information

- Anti

- The actor states in the article that they are opposed to a general right to government information; or, the article describes the actor as being opposed to a general right to government information

- Neutral or mixed

- The actor states in the article that they are neutral or ambivalent about a general right to government information; or, the article describes the actor as being neutral or ambivalent about a general right to government information

- The actor expresses both support and opposition to a general right to government information; or, the article describes the actor as both supporting and opposing a general right to government information

- Unclear

- The actor's support or opposition to a general right to government information cannot be determined in the article

- Actor's Rationale for their Core Belief on Access to Government Information

- Coded as one or more of the following (select as many as apply):

- Corruption

- Government spending/waste

- Economic growth and development

- Democracy, transparency and accountability

- Public demand

- International image

- Legislation goes too far (i.e., the legislation allows too much access to information)

- Legislation does not go far enough (i.e., the legislation allows too little access to information)

- Need for more study/information

- Electoral mandate (i.e., actor was elected to pursue/block reform)

- Improve journalism

- Other

- Unclear 
Appendix B: Actors with Pro-Transparency Core Beliefs

\begin{tabular}{|c|c|c|c|c|}
\hline Org. Types & $\begin{array}{l}\text { 2000-09 } \\
\text { Pres. Kufuor } \\
\text { (NPP) }\end{array}$ & $\begin{array}{l}\text { 2009-12 } \\
\text { Pres. Mills } \\
\text { (NDC) }\end{array}$ & $\begin{array}{l}\text { 2012-17 } \\
\text { Pres. Mahama } \\
\text { (NDC) }\end{array}$ & $\begin{array}{l}\text { 2012-17 } \\
\text { Pres. Mahama } \\
\text { (NDC) }\end{array}$ \\
\hline $\begin{array}{l}\text { Domestic } \\
\text { NGOs }\end{array}$ & $\begin{array}{l}\text { Ghana Bar } \\
\text { Association } \\
\text { (GBA) } \\
\text { Ghana } \\
\text { Integrity } \\
\text { Initiative } \\
\text { Ghana } \\
\text { Journalist } \\
\text { Association } \\
\\
\text { Institute of } \\
\text { Economic } \\
\text { Affairs }\end{array}$ & $\begin{array}{l}\text { Construction } \\
\text { and Building } \\
\text { Materials } \\
\text { Workers Union } \\
\text { (CBMWU) of } \\
\text { Trades Union } \\
\text { Congress (TUC) } \\
\\
\text { Editors Forum } \\
\text { Ghana (EFG) } \\
\\
\text { Ghana Aid } \\
\text { Effectiveness } \\
\text { Forum (GAEF) } \\
\text { Ghana Trades } \\
\text { Union Congress } \\
\text { Ghana Bar } \\
\text { Association } \\
\text { (GBA) } \\
\text { Ghana } \\
\text { Integrity } \\
\text { Initiative } \\
\text { Association }\end{array}$ & $\begin{array}{l}\text { Architects } \\
\text { Registration } \\
\text { Council (ARC) } \\
\text { Association of } \\
\text { Building \& Civil } \\
\text { Engineers } \\
\text { Contractors } \\
\text { Ghana } \\
\text { (ABCECG) } \\
\text { Association of } \\
\text { Ghana Industries } \\
\text { (AGI) }\end{array}$ & $\begin{array}{l}\text { Media } \\
\text { Foundation for } \\
\text { West Africa } \\
\text { (MFWA) }\end{array}$ \\
\hline
\end{tabular}




\begin{tabular}{|c|c|c|c|}
\hline $\begin{array}{l}\text { National African } \\
\text { Peer Review } \\
\text { Mechanism } \\
\text { Governing } \\
\text { Council } \\
\text { (NAPRM-GC) } \\
\text { National Union } \\
\text { of Ghana } \\
\text { Students } \\
\text { (NUGS) }\end{array}$ & $\begin{array}{l}\text { Human Rights } \\
\text { Advocacy Center } \\
\text { (HRAC) } \\
\\
\text { Institute of } \\
\text { Democratic } \\
\text { Governance } \\
\text { (IDEG) } \\
\\
\text { Institute of } \\
\text { Economic } \\
\text { Affairs } \\
\text { National Union } \\
\text { of Ghana } \\
\text { Students } \\
\text { (NUGS) }\end{array}$ & $\begin{array}{l}\text { Ghana Bar } \\
\text { Association } \\
\text { (GBA) } \\
\text { Ghana } \\
\text { Community } \\
\text { Radio Network } \\
\text { (GCRN) } \\
\text { Ghana } \\
\text { Independent } \\
\text { Broadcasters } \\
\text { Association } \\
\text { (GIBA) } \\
\text { GIonation } \\
\text { Ghana Medical } \\
\text { Association (GMA) } \\
\text { Journalist } \\
\text { Integrity } \\
\text { Ghana } \\
\text { Ghana Institute } \\
\text { of Architects } \\
\text { (GIA) } \\
\text { Ghana Institute } \\
\text { of Planners } \\
\text { (GIP) } \\
\text { Ghana Institute } \\
\text { of Public Policy } \\
\text { Options } \\
\text { (GIPPO) } \\
\end{array}$ & $\begin{array}{l}\text { Networking } \\
\text { Center of } \\
\text { SEND-Ghana } \\
\text { Occupy Ghana } \\
\text { RTI Coalition }\end{array}$ \\
\hline
\end{tabular}




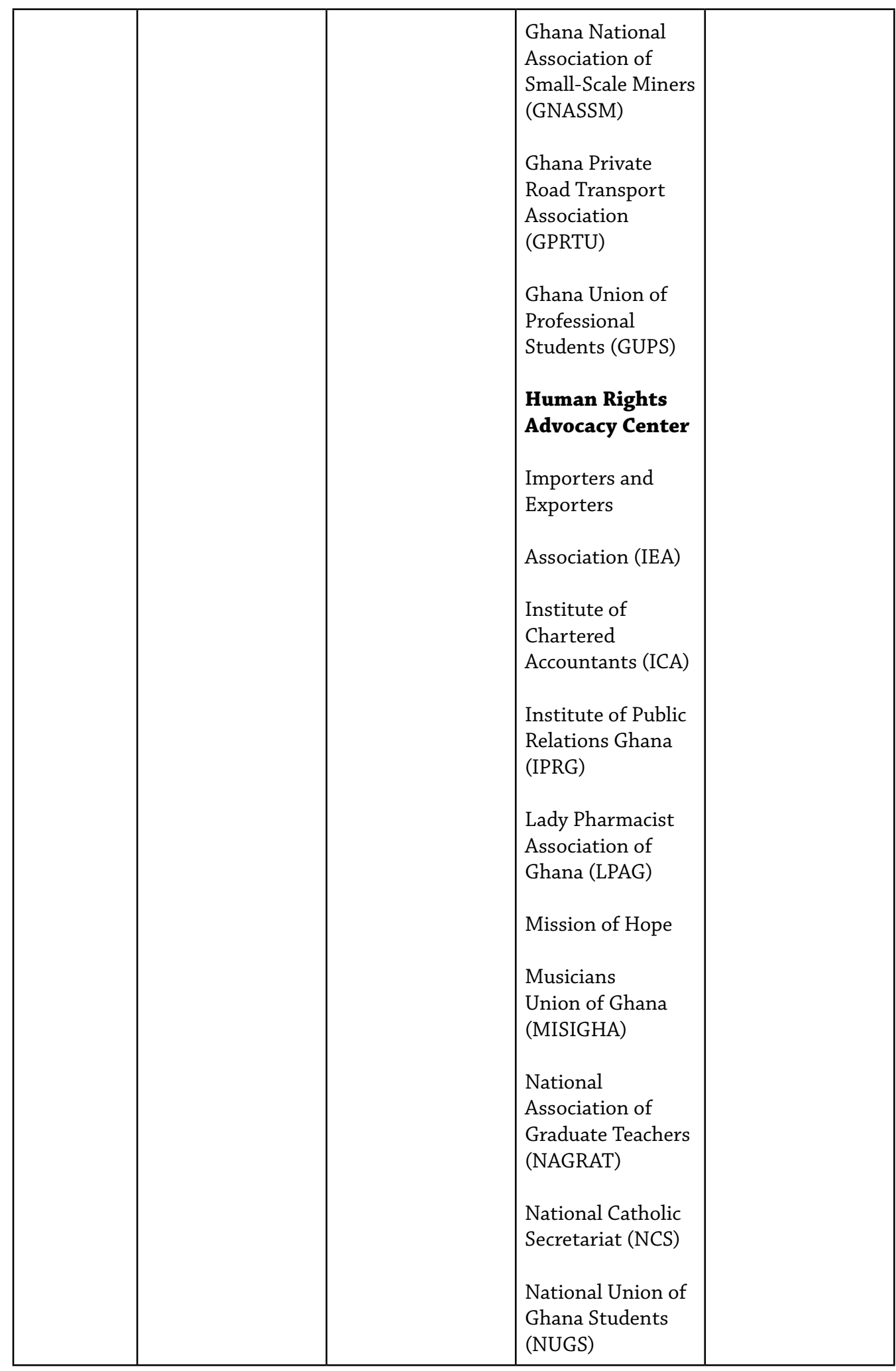




\begin{tabular}{|c|c|c|c|c|}
\hline & & & 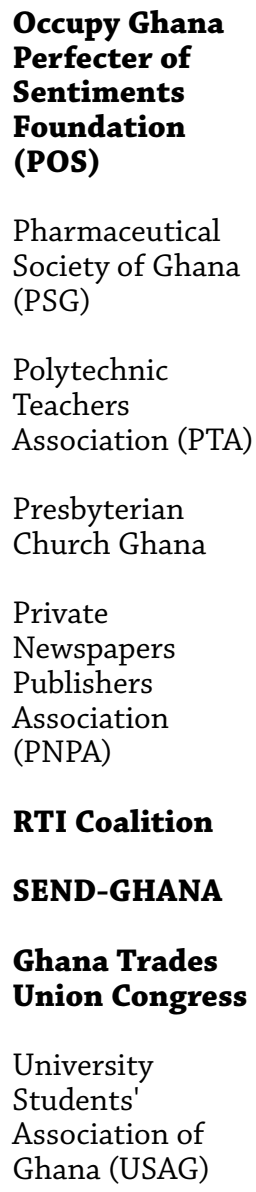 & \\
\hline Int'l NGOs & $\begin{array}{l}\text { Commonwealth } \\
\text { Human } \\
\text { Rights } \\
\text { Initiative } \\
\text { (CHRI) } \\
\text { The World Bank } \\
\text { Institute }\end{array}$ & $\begin{array}{l}\text { Africa Freedom } \\
\text { of Information } \\
\text { Center (AFRIC) } \\
\text { Amnesty } \\
\text { International } \\
\text { Ghana } \\
\text { Commonwealth } \\
\text { Human } \\
\text { Rights } \\
\text { Initiative } \\
\text { (CHRI) } \\
\text { Media } \\
\text { Foundation } \\
\text { for West Africa } \\
\text { (MFWA) }\end{array}$ & $\begin{array}{l}\text { All Africa } \\
\text { Students Union } \\
\text { (AASU) } \\
\text { Commonwealth } \\
\text { Human } \\
\text { Rights } \\
\text { Initiative } \\
\text { (CHRI) } \\
\\
\text { Deutsche Welle } \\
\text { Akademie (DW } \\
\text { Akademie) }\end{array}$ & $\begin{array}{l}\text { Commonwealth } \\
\text { Human } \\
\text { Rights } \\
\text { Initiative } \\
\text { (CHRI) } \\
\\
\text { European Union } \\
\text { Election Obser- } \\
\text { vation Mission } \\
\text { (EUOM) }\end{array}$ \\
\hline
\end{tabular}




\begin{tabular}{|c|c|c|c|c|}
\hline $\begin{array}{l}\text { Govt. } \\
\text { Entities }\end{array}$ & $\begin{array}{l}\text { Attorney } \\
\text { General and } \\
\text { Ministry of } \\
\text { Justice } \\
\text { Ministry of } \\
\text { Information } \\
\text { National } \\
\text { Commission } \\
\text { for Civic } \\
\text { Education } \\
\text { (NCCE) } \\
\text { National Media } \\
\text { Commission } \\
\text { Office of the } \\
\text { President }\end{array}$ & 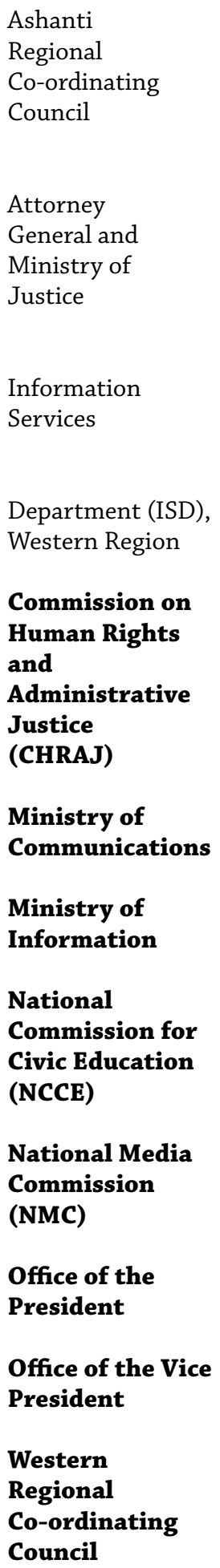 & $\begin{array}{l}\text { Ghana Revenue } \\
\text { Authority } \\
\text { Minerals } \\
\text { Commission } \\
\text { Ministry of } \\
\text { Information and } \\
\text { Media Relations } \\
\\
\text { Office of the } \\
\text { President }\end{array}$ & $\begin{array}{l}\text { Attorney } \\
\text { General and } \\
\text { Ministry of } \\
\text { Justice } \\
\text { Commission on } \\
\text { Human Rights } \\
\text { and } \\
\text { Administrative } \\
\text { Justice } \\
\text { (CHRAJ) } \\
\\
\text { Ministry of } \\
\text { Information } \\
\text { National } \\
\text { Commission } \\
\text { for Civic } \\
\text { Education } \\
\text { (NCCE) }\end{array}$ \\
\hline
\end{tabular}




\begin{tabular}{|c|c|c|c|c|}
\hline $\begin{array}{l}\text { Political } \\
\text { Parties }\end{array}$ & $\begin{array}{l}\text { National } \\
\text { Democratic } \\
\text { Congress } \\
\text { New Patriotic } \\
\text { Party }\end{array}$ & $\begin{array}{l}\text { Convention } \\
\text { Peoples' Party } \\
\text { National } \\
\text { Democratic } \\
\text { Congress } \\
\text { New Patriotic } \\
\text { Party }\end{array}$ & $\begin{array}{l}\text { Convention } \\
\text { Peoples' Party } \\
\text { National } \\
\text { Democratic } \\
\text { Congress } \\
\text { New Patriotic } \\
\text { Party } \\
\text { Progressive } \\
\text { People's Party }\end{array}$ & $\begin{array}{l}\text { New Patriotic } \\
\text { Party } \\
\text { Progressive } \\
\text { People's Party } \\
\text { National } \\
\text { Democratic } \\
\text { Congress }\end{array}$ \\
\hline Journalists & Diamond FM & $\begin{array}{l}\text { Enquirer } \\
\text { Newspaper } \\
\text { Ghana } \\
\text { Broadcasting } \\
\text { Corporation (GBC) }\end{array}$ & & $\begin{array}{l}\text { New Crusading } \\
\text { Guide }\end{array}$ \\
\hline $\begin{array}{l}\text { Academics/ } \\
\text { Consult- } \\
\text { ants }\end{array}$ & $\begin{array}{l}\text { University of } \\
\text { Ghana School of } \\
\text { Communication } \\
\text { Studies }\end{array}$ & & & $\begin{array}{l}\text { Ghana Institute of } \\
\text { Management and } \\
\text { Public } \\
\text { Administration } \\
\text { (GIMPA) } \\
\text { Kwame Nkrumah } \\
\text { University of } \\
\text { Science and } \\
\text { Technology } \\
\text { (KNUST) } \\
\text { University of } \\
\text { Ghana School of } \\
\text { Communication } \\
\text { Studies }\end{array}$ \\
\hline Others & Judiciary & $\begin{array}{l}\text { Human Rights } \\
\text { Network of } \\
\text { Uganda } \\
\text { (HURINET) } \\
\\
\text { Joint Committee } \\
\text { on Constitutional, } \\
\text { Legal \& } \\
\text { Parliamentary } \\
\text { Affairs }\end{array}$ & $\begin{array}{l}\text { Select } \\
\text { Committee on } \\
\text { Constitutional, } \\
\text { Legal \& } \\
\text { Parliamentary } \\
\text { Affairs }\end{array}$ & $\begin{array}{l}\text { Chamber of } \\
\text { Bulk Oil } \\
\text { Distributors } \\
\text { Committee on } \\
\text { Constitutional, } \\
\text { Legal and } \\
\text { Parliamentary } \\
\text { Affairs }\end{array}$ \\
\hline
\end{tabular}




\begin{tabular}{|l|l|l|l|}
\hline & & UT Group & \\
& $\begin{array}{l}\text { National Unions of } \\
\text { Civil Engineering } \\
\text { Construction, } \\
\text { Furniture and } \\
\text { Wood Workers of } \\
\text { Nigeria } \\
\text { Embassy in }\end{array}$ \\
(NUCECFWW) & & \\
Ghana
\end{tabular}

\section{Appendix C: Prominent Corruption Scandals in Ghana (2009-18)}

- Ghana Youth Employment and Entrepreneurial Development Agency (GYEEDA) scandal: In 2013, a journalist investigated the operations of GYEEDA and uncovered massive corruption. The government set up a five-member committee to probe the allegations and the findings largely corroborated the allegations. This led to the cancellation of all GYEEDA contracts with service providers.

- Bus Branding scandal: In 2015, investigations into the branding of 116 Metro Mass Transit Buses involving GH\$3.6million revealed that the company contracted, Smarttys, over-billed the government to the tune of about GH\$1.9million.

- Savanna Accelerated Development Authority (SADA) scandal: In 2014, investigation revealed that Ghana's Accelerated Development Authority (SADA) had embezzled millions of dollars allocated to it. The inquiries showed that SADA paid GH $\$ 32,498,000$ to ACICL to plant 
five million trees in the savannah zone but could only account for about 700,000 trees. It also found that SADA spent GH $\$ 15$ million on guinea fowl but could only account for a few of the birds.

- WOYOMEGATE: The Government of the National Democratic Congress (NDC), under President John Evans Atta-Mills, fraudulently paid a financier of the party GH\$51.2 million between 2010 and 2011. In July 2014 the Supreme Court ordered Woyome to pay the money back to the state, but the businessman did not do that.

- Mahama Ford Gift scandal: An investigation by Joy FM's Manasseh Azure Awuni revealed in June 2016 that President John Mahama received a Ford Expedition vehicle, estimated to cost $\$ 100,000$, from a Burkinabe contractor, Djibril Kanazoe. This sparked condemnation from a section of the public. Opposition politicians and some society organisations accused the President of receiving a bribe, especially after it emerged that the businessman had won two government contracts worth over GH\$100 million after the President received the vehicle.

- Financial Malfeasance at the National Service Secretariat: In 2014, officials of the Bureau of National Investigations (BNI) uncovered a GH\$7.9 million deep-rooted rot at the National Service Secretariat (NSS). Investigations showed that the amount represented the allowance paid to 22,612 non-existent service people in more than 100 districts across the country.

- Mobile Money Interoperability debacle: The NPP government cancelled an existing contract for the development of a mobile money interoperability system in 2017 and entered into a new arrangement to develop the same at a reduced cost. The new system cost the country less than $\$ 4$ million, relative to the earlier $\mathrm{GH} \$ 4.6$ billion contract amount.

- Cocoa Marketing Board (COCOBOD) scandal: Joseph Boahen Aidoo, the Chief Executive Office of the COCOBOD, alleged that Dr Opuni (former CEO) had conspired with some top officials of COCOBOD to siphon cocoa cash. A whopping $\$ 400$ million was reported to have been expended during the transition period - between December 20, 2016 and January 6, 2017.

- Social Insurance and National Insurance Trust (SNNIT) software scandal: The Ghana Social Security and National Insurance Trust (SSNIT) software corruption scandal involved the procurement of ICT infrastructure at a cost of $\$ 72$ million, a price tag that was well over the initial amount estimated for the project. The investigation was started in August 2017 by the Economic and Organized Crime Office (EOCO) after the allegations became known.

- Bulk Oil and Storage Transportation (BOST) saga: Bulk Oil Storage and Transportation (BOST) was accused of fraudulently selling five million litres of contaminated fuel to two unlicensed companies, Movepiina and Zup Oil, which were allegedly set up few days before the sale, making Ghana lose about GH\$7 million in revenue.

- Metro Mass Transit scandal: The staff union of the transport company petitioned the Transport Minister to demand the removal of Mr Aboagye for full-scale investigations into his alleged corruption and procurement breaches. Mr Aboagye was accused of breaching several procurement laws in the acquisition of some 300 buses since taking over the company in 2017. 